Akuntansi dan Manajemen

Vol. 16, No. 2, 2021, Hal.191-214

\title{
Pengukuran Kinerja Keuangan Dengan Rasio Arus Kas Pada Perusahaan Pertambangan yang Terdaftar di BEI
}

\author{
Yuni Rachmawati', Muhni Pamuji ${ }^{2}$ \\ 1Jurusan Akuntansi, Universitas Tridinanti Palembang \\ Email: yunirachmawatise@gmail.com \\ 2Jurusan Manajemen, Universitas Tridinanti Palembang \\ Email: muhnipamuji@gmail.com
}

\begin{abstract}
This research was conducted to determine the financial performance of mining companies listed on the Indonesia Stock Exchange in 2017-2019. Mining companies were selected for research because this industry was not included in the business fields that were reported to support the Indonesian economy in 2019, especially with the outbreak of the Covid-19 pandemic. The high death rate and the rapid spread of this virus have made policies from the government, including limiting activities both domestically and internationally. Even some import-export destination countries have locked down, which of course will affect the productivity and financial performance of the mining industry. From a population of 47 mining companies, only 10 companies met the criteria and were selected as samples. The type of data used is quantitative data. Secondary data sources. Financial performance is measured using a cash flow ratio consisting of 5 liquidity ratios and 2 flexibility ratios. The results showed that based on the cash flow ratio, the majority of mining companies did not have good performance and were still below the standard. Of the eight ratios, only the cash coverage ratio is the most achievable by mining companies. The value of the cash flow ratio of mining companies has decreased during the Covid-19 pandemic.
\end{abstract}

Keywords: performance, finance, mining, ratio, cash flow

\begin{abstract}
ABSTRAK
Penelitian ini dilakukan untuk mengetahui kinerja keuangan perusahaan pertambangan yang terdaftar di BEI tahun 2017-2019. Perusahaan pertambangan dipilih untuk diteliti karena industri ini tidak termasuk dalam lapangan usaha yang dilaporkan mendukung ekonomi Indonesia di tahun 2019, terlebih lagi dengan mewabahnya pandemi Covid-19. Tingginya angka kematian serta cepatnya penyebaran virus ini sehingga dibuat kebijakan dari pemerintah yaitu diantaranya pembatasan aktivitas baik domestik maupun internasional. Bahkan beberapa negara tujuan ekspor impor melakukan lockdown, yang tentunya akan mempengaruhi produktivitas serta kinerja keuangan industri pertambangan. Dari populasi sebanyak 47 perusahaan pertambangan, hanya 10 perusahaan yang memenuhi kriteria dan dipilih untuk menjadi sampel. Jenis data yang digunakan adalah data kuantitatif. Sumber data sekunder. Kinerja keuangan diukur menggunakan rasio arus kas yang terdiri dari 5 rasio likuiditas dan 2 rasio fleksibilitas. Hasil penelitian menunjukkan bahwa berdasarkan rasio arus kas, mayoritas perusahaan pertambangan belum memiliki kinerja yang baik dan masih dibawah standar. Dari delapan rasio hanya rasio cakupan kas yang paling banyak mampu dicapai oleh perusahaan pertambangan. Nilai rasio arus kas perusahaan pertambangan semakin menurun selama pandemi Covid-19.
\end{abstract}

Kata Kunci : kinerja, keuangan, pertambangan, rasio, arus kas 


\section{Pendahuluan}

Pengukuran kinerja keuangan perusahaan sangat perlu dilakukan. Melalui pengukuran kinerja keuangan, manajemen dapat review dan mengevaluasi tingkat efisiensi dan efektivitas organisasi dalam mencapai tujuan yang telah ditetapkan pada periode berjalan. Pengukuran kinerja juga berperan dalam pengambilan keputusan ekonomi yang akan diambil para pemangku kepentingan.

Kinerja keuangan suatu perusahaan dapat tercermin dari laporan keuangan yang disajikan per periode pelaporan. Laporan keuangan merupakan alat komunikasi yakni aktivitas perusahaan dengan stakeholders maupun shareholders. Dari laporan keuangan yang disajikan perusahaan dapat diperoleh informasi mengenai posisi keuangan dan hasil operasi yang telah dicapai oleh perusahaan tersebut. Laporan keuangan yang lengkap terdiri dari Laporan Perubahan Posisi Keuangan atau Neraca, Laporan Laba Rugi, Laporan Perubahan Ekuitas, Laporan Arus Kas dan CALK -Catatan Atas Laporan Keuangan.

Penilaian atas kinerja keuangan perusahaan terkategori baik atau tidak, dapat diperoleh melalui suatu analisis laporan keuangan. Terdapat keharusan bagi perusahaan untuk menyajikan laporan arus kas dalam laporan keuangan tahunan, artinya penggunaan informasi laporan arus kas sebagai alat analisis kinerja perusahaan juga sangatlah penting untuk dilakukan. Pemikiran penulis sejalan dengan hasil penelitian yang dilakukan oleh Dwi, yang menyatakan bahwa kas merupakan item yang paling berguna. Dalam pengambilan keputusannya para kreditor investor dan stakeholders lain memfokuskan pada penilaian arus kas di masa depan. Idle cash akan memanfaatkan entitas dengan berinvestasi jangka pendek yang sangat likuid [3].

Perusahaan diharapkan tidak memiliki kesulitaan yang signifikan dalam aspek likuiditas. Kesulitan entitas dalam menghasilkan kas dapat mengakibatkan perusahaan kehilangan kredibilitas, juga kontinuitas yang diragukan. Hal ini bisa menjadi indikator bagaimana manajemen melakukan evaluasi terkait usaha perusahaan dalam mencapai tujuan yang telah ditetapkan sebelumnya. Investor akan melihat kas yang dihasilkan dari aktivitas operasi, kemudian mempertimbangkan perusahaan mana yang akan dipilih untuk berinvestasi dari tingkat profitabilitas dan penanaman modalnya.

Penelitian mengenai pengukuran kinerja keuangan telah banyak dilakukan, umumnya menggunakan rasio profitabilitas, likuiditas, solvabilitas dan rentabilitas, namun belum banyak yang menggunakan rasio arus kas. Penelitian terkait analisis laporan keuangan dengan rasio arus kas diantaranya dilakukan oleh Jona [12], Syahputra [25], Mulyani [16], Sanusi [22], dll.

Semua perusahaan tentu menginginkan suatu penilaian yang baik atas perusahaannya, terlebih lagi penilaian ini akan berpengaruh juga terhadap nilai sahamnya. Berdasarkan data dari Badan Pusat Statistik bahwa pertumbuhan ekonomi Indonesia pada triwulan kedua tahun 2019 didukung oleh semua lapangan usaha namun tidak termasuk sektor tambang dan penggalian. Menurut Suharyanto, Kepala BPS, terjadi penurunan yang terlihat dari ADHB - Atas Dasar Harga Berlaku dan ADHK - Atas Dasar Harga Konstan pada sektor pertambangan dan penggalian ini. Pada triwulan kedua tahun 2019, ADHB dan ADHK pertambangan dan penggalian mengalami penurunan. ADHB pertambangan dan penggalian turun Rp 1,3 triliun yakni menjadi Rp292,6 triliun sedangkan ADHK turun sebesar 1,2 triliun dari triwulan sebelumnya. 
Menurut situs Kontan.co.id, pada kuartal pertama tahun 2019 sebagian badan usaha tambang sejenis telah menyampaikan kinerja perusahaannya. Dan hasilnya hingga kuartal pertama tahun 2019 ini sektor tambang masih menjadi sektor yang harus mendapat perhatian serius. Laba bersih perusahaan tambang yang turun terjal, diantaranya PT Indika Energy Tbk yang melaporkan mengalami penurunan laba yang sangat signifikan yakni turun $61 \%$ atau hanya US\$ 40,5 juta. Selain itu, INDY, pada periode tersebut melaporkan profit US\$103,8 juta. Selanjutnya kemerosotan laba bersih juga terjadi pada PT Bukit Asam Tbk yakni 21,4\% sedangakan year on year (yoy) menjadi $\mathrm{Rp} 1,14$ triliun. Berbeda dengan perusahaan yang mengalami kemerosotan, justru PT Kapuas Prima Coal Tbk melaporkan labanya mengalami kenaikan 3,35\% secara tahunan yakni mencapai Rp 42,13 miliar. BRMS-PT Bumi Resources Minerals melaporkan net income ditahun yang sama yakni US\$ 86.650, dimana sebelumnya BRMS mencetak rugi bersih US\$ 4,69 juta.

Awal tahun 2020 ini, dunia dikejutkan dengan penyebaran virus Covid-19 yang meluas cepat hampir ke semua negara. Virus Covid-19 ini bermula terdeteksi di negara Wuhan, Provinsi Hubei, China pada Desember 2019. Tidak terkecuali Indonesia, Corona Virus Disease 19 (Covid - 19) tidak dapat dielakkan dan diputuskan sebagai pandemi oleh World Health Organization (WHO). Berdasarkan data dari Worldmeter, per 21 Juni 2020 jumlah penduduk Indonesia yang terkonfirmasi positif virus Covid-19 sebanyak 43.803 orang, meninggal dunia sebanyak 2.373 orang sehingga tingkat kematian karena terpapar virus Covid-19 adalah 5,42 \%. Tingkat kematian karena Covid-19 di Indonesia menempati urutan ke-empat setelah Italy, Inggris, dan Spanyol.

Tingginya tingkat kematian dan cepatnya penyebaran virus Covid-19 ini membuat pemerintah menerapkan berbagai aturan, diantaranya pembatasan aktivitas bekerja dengan memberlakukan WFH dan WFO, PSBB atau pembatasan jam operasional perusahaan, bahkan pembatasan akses ekspor impor. Pandemi ini tentu berdampak ke berbagai jenis sektor, tidak hanya sektor kesehatan tetapi juga sektor lain termasuk pertambangan. Beberapa negara memberlakukan lockdown. Karantina wilayah (lockdown) di China pada kuartal pertama tahun 2020. Selanjutnya diikuti negara lain, diantaranya India dan Philipina. Adanya lockdown ini memiliki dampak dan pengaruh paling besar terhadap permintaan batu bara. Pergerakan batu bara Indonesia sangat terdampak dengan adanya karantina wilayah di beberapa negara diatas, mengingat 65\% dari total ekspor batu bara Indonesia dituju kepada ketiga negara tersebut. Bersumber dari McKinsey\&Company bahwa penurunan permintaan sebagai dampak langsung dari COVID-19 di tahun berjalan 2020 diperkirakan sebesar 85.0mt. lebih lanjut lagi, terdapat potensi penurunan permintaan lebih lanjut jika "lockdown" diperpanjang melebihi dari jadwal yang sudah diumumkan sebelumnya.

Terlait latar belakang inilah, peneliti akan menganalisis kinerja keuangan perusahaan pertambangan melalui analisis rasio arus kas dalam tiga periode terakhir yaitu 2017 hingga tahun 2019. Selain itu penulis juga akan membandingkan kinerja per triwulan sebelum dan selama dilanda pandemi Covid-19 yakni tahun 2019 dengan tahun 2020. 


\section{Tinjauan Pustaka}

\section{Kinerja Keuangan}

Kinerja keuangan adalah suatu studi yang dilakukan dengan tujuan melihat sejauh mana perusahaan telah melaksanakan aturan-aturan serta implementasi atas keuangan [5]. Sedangkan menurut Rudianto, kinerja keuangan merupakan hasil atau prestasi yang telah dicapai oleh manajemen perusahaan dalam menjalankan fungsinya mengelola aset perusahaan secara efektif selama periode tertentu. Kinerja keuangan sangat dibutuhkan oleh perusahaan untuk mengetahui dan mengevaluasi sampai dimana tingkat keberhasilan perusahaan berdasarkan aktivitas keuangan yang telah dilaksanakan [20].

Tujuan dari pengukuran kinerja keuangan perusahah adalah mengetahui tingkat likuiditas, tingkat rentabilitas, tingkat solvabilitas, tingkat stabilitas / fleksibilitas [17]. Tujuan pengukuran kinerja keuangan adalah untuk memberikan informasi yang dibutuhkan dalam pengambilan keputusan penting mengenai aset, mengukur kinerja unit usaha sebagai suatu entitas usaha[21]. Selain itu kinerja keuangan juga digunakan sebagai fondasi awal dalam memperkirakan perubahan potensial sumber daya ekonomi yang mungkin dikendalikan dimasa depan

Irham Fahmi menjelaskan bahwa secara umum ada lima tahapan dalam menelaah kinerja atau prestasi keuangan suatu perusahaan, yaitu mengevaluasi laporan keuangan, membuat perhitungan, membuat komparasi atas perhitungan yang telah diperoleh, melakukan penafsiran terhadap berbagai permasalahan yang ditemui, dan mencari serta memberikan saran sebagai jalan keluar atas permasalahan yang muncul [5].

Laporan keuangan menunjukkan kondisi keuangan dan hasil upaya suatu entitas pada masa dan tenggang waktu tertentu serta sarana terpenting dalam menilai prestasi dan kondisi ekonomis suatu perusahaan [6]. Laporan keuangan merupakan salah satu sumber yang penting bagi para pemakai laporan keuangan dalam rangka pengambilan keputusan ekonomi. Laporan keuangan ini akan menjadi lebih bermanfaat apabila informasi yang terkandung dalam laporan keuangan tersebut dapat digunakan untuk memprediksi apa yang akan terjadi dimasa yang akan datang [7].

Menurut Arief, pengguna atas laporan keuangan diklasifikasikan menjadi dua yaitu pihak internal dan pihak eksternal [1]. Sedangkan menurut Subramanyan, keterikatan pada intuisi, tebakan dan firasat dalam pengambilan keputusan, serta ketidakpastian analisis bisnis analisis laporan keuangan dapat dikurangi melalui analisis laporan keuangan[23].

\section{Laporan Arus Kas}

Menurut Rudianto, laporan arus kas adalah suatu laporan tentang aktivitas penerimaan dan pengeluaran kas perusahaan dalam suatu periode tertentu, beserta penjelasan tentang berbagai sumber penerimaan \& pengeluaran kas tersebut [20]. Sedangkan menurut Ikatan Akuntan Indonesia, laporan arus kas menyajikan arus kas selama kurun waktu tertentu dan dikelompokkan berdasarkan aktivitas investasi, aktivitas pendanaan, serta aktivitas operasi [9]. 
https://akuntansi.pnp.ac.id/jam

Analisis Rasio Arus Kas

Tidak hanya alat-alat finansial, Analisis terhadap rasio laporan arus kas adalah analisis atas keuangan yang sangat penting dilakukan manajer keuangan. Melalui analisis atas laporan arus kas, salah satu fungsi perusahaan dapat dilaksanakan dengan baik yaitu fungsi perencanaan. Laporan arus kas harus disajikan menurut ketentuan Pernyataan Standar Akuntansi Keuangan. Dalam Darsono dan Ashari, Arus kas suatu perusahaan perlu dianalisis untuk mengevaluasi kinerja finansial diantaranya yaitu menggunakan Rasio Fleksibilitas Arus Kas dan Rasio Likuiditas Arus Kas [3]. Rasio Likuiditas Arus Kas terdiri dari enam (6) rasio, yaitu AKO, CAD, CKB, CKHL, Rasio Pengeluaran Modal, dan TH. Berikut penjelasan masing-masing rasio dan indikator.

\section{Rasio Arus Kas Operasi (AKO)}

Rasio Arus Kas Operasi menunjukkan kapabilitas arus kas operasi dalam membayar kewajiban lancar yang diperoleh dari membandingkan arus kas operasi terhadap kewajiban lancar.

$$
A K O=\frac{\text { Jumlah Arus Kas Operasi }}{\text { Kewajiban Lancar }}
$$

Perusahaan dianggap mampu membayar kewajiban lancar tanpa tergantung pada arus kas dari aktivitas lain jika nilai AKO minimal bernilai 1 (satu)

\section{Rasio Cakupan Arus Dana (CAD)}

Dengan Rasio CAD dapat diketahui kesanggupan entitas untuk mendapatkan kas yang bisa digunakan untuk membayar deviden preferen, pajak,dan beban bunga serta komitmen lainnya. Rasio ini didapat dari membandingkan EBIT terhadap bunga, pembayaran dividen serta hutang pajak.

$$
C A D=\frac{E B I T}{\text { Bunga }+ \text { Pajak }+ \text { Dividen }}
$$

Rasio yang bernilai minimal 1 (satu) menginterpretasikan bahwa entitas yang dianalisis memiliki kecukupan yang lebih baik dari laba sebelum pajak untuk menutup hutang -hutang yang jatuh tempo dalam satu tahun.

\section{Rasio Cakupan Kas terhadap Bunga (CKB)}

Rasio CKB ini digunakan untuk mengetahui kapabilitas suatu entitas untuk melunasi bunga hutang. Rasio ini dapat dihitung dengan membandingkan penjumlahan arus kas operasi dan pembayaran bunga serta pajak terhadap pembayaran bunga.

$$
C K B=\frac{\text { Arus Kas Operasi }+ \text { Pembayaran Bunga }+ \text { Pajak }}{\text { Pembayaran Bunga }}
$$


Bila nilai rasio CKB lebih dari 1 dipercayakan bahwa arus kas operasi perusahaan memiliki kapabilitas yang lebih baik untuk menutup biaya bunga. Artinya kemungkinan tidak mampu membayar bunga perusahaan tersebut sangat kecil.

\section{Rasio Cakupan Kas terhadap Hutang Lancar (CKHL)}

Rasio CKHL ini diperuntukkan menaksir kapabilitas entitas dalam melunasi hutang yang segera jatuh tempo dengan bersumber pada arus kas operasi bersih. Rasio CKHL didapat dengan membandingkan jumlah arus kas operasi dan dividen terhadap hutang jangka pendek atau hutang lancarnya.

$$
C K H L=\frac{\text { Arus Kas Operasi }+ \text { Dividen }}{\text { Hutang Lancar }}
$$

Berbeda dengan standar rasio sebelumnya, suatu perusahaan dianggap memiliki kapabilitas baik dari arus kas operasi dalam menutup hutang lancar jika memiki rasio CKHL diatas 0,4 .

\section{Rasio Pengeluaran Modal}

Rasio Pengeluaran Modal diyakini dapat dipakai untuk memperkirakan modal tersedia bagi investasi dan pembayaran hutang. Rasio pengeluaran modal ini didapat dengan membandingkan arus kas operasi terhadap pengeluaran modal perusahaan.

$$
P M=\frac{\text { Arus Kas Operasi }}{\text { Pengeluaran Modal }}
$$

Suatu perusahaan dianggap mempunyai kapabilitas yang tinggi dari arus kas dalam membiayai pengeluaran modal jika memiliki nilai rasio minimal 1 (satu).

\section{Rasio Total Hutang (TH)}

Rasio TH- total hutang didapatkan dengan membandingkan arus kas operasi terhadap total hutang. Rasio TH ini ditaksir dapat mengetahui jangka waktu kapabilitas entitas bisa membayar hutang menggunakan arus operasi.

Dengan rasio ini, suatu perusahaan akan dianggap mempunyai kapabilitas yang baik untuk membayar semua hutangnya dengan menggunakan arus kas dari aktivitas normal operasi perusahaan jika memiliki nilai rasio diatas 0,2 .

$$
T H=\frac{\text { Arus Kas Operasi }}{\text { Total Hutang }}
$$

\section{Rasio Fleksibilitas Arus Kas}

Rasio ini mencakup dua (2) rasio yaitu Rasio Kecukupan Arus Kas (KAK) dan Rasio Arus Kas Bersih Bebas AKBB, berikut penjelasannya. 


\section{Rasio Kecukupan Arus Kas (KAK)}

Rasio Kecukupan Arus Kas (KAK) dipakai dalam memprediksi entitas dalam menyiapkan kas yang digunakan untuk melunasi kewajibannya dalam kurun waktu lima tahun kedepan. Rasio KAK didapatkan dengan membandingkan jumlah laba sebelum pajak dan bunga dikurangi pembayaran pajak juga pembayaran bunga serta pengeluaran modal terhadap hutang rata-rata yang jatuh tempo setiap tahun selama 5 tahun.

$$
K A K=\frac{E B I T-\text { Bunga }- \text { Pajak }- \text { Pengeluaran Modal }}{\text { Rata }- \text { rata Hutang Lancar selama } 5 \text { tahun }}
$$

Suatu perusahaan akan dianggap memiliki kepabilitas yang rendah dalam menyediakan kas guna menyelesaikan kewajibannya dalam jangka 5 tahun kedepan jika memiliki nilai Rasio KAK dibawah angka 1.

\section{Rasio Arus Kas Bersih Bebas (AKBB)}

Rasio Arus Kas Bersih Bebas diprediksi mampu menilai kapabilitas entitas untuk menyelesaikan kewajiban kas dimasa depan. Rasio AKBB diperoleh dari komparatif atas penjulahan laba bersih,beban bunga,depresiasi dan amortisasi ,biaya sewa dan leasingdikurangkan dengan pengeluaran modal terhadap total biaya bunga dikapitalisasi dan diakui ditambah dengan biaya sewa dan leasing operasi,proporsi hutang jangka panjang dan sekarang.

$$
A K B B=\frac{\text { Laba Besih }+ \text { Bunga }+ \text { Depresiasi }+ \text { Leasing }+ \text { Deviden }- \text { Peng. Modal }}{\text { Bunga }+ \text { Hutang Jangka Panjang }+ \text { Hutang Leasing }}
$$

Suatu entitas akan dinilai memiliki kapabilitas untuk bertahan dan berkembang dimasa depan hany jika memiliki nilai rasio AKBB dengan nilai minimal 1.

\section{Pandemi Covid-19}

Menurut Amesh Adalja, Wabah COVID-19 merupakan model penyebaran infeksi novel coronavirus. Penyakit ini kemungkinan besar menjadi pandemi, yakni penyakit yang meluas ke seluruh belahan dunia. Sedangkan menurut Sayekti, bahwa Coronavirus Disease (Covid-19) adalah penyakit menular yang disebabkan oleh virus corona yang baru ditemukan dan dikenal sebagai sindrom pernafasan akut atau parah virus corona 2 .

\section{Metode Penelitian}

Penelitian ini merupakan model analisis kuantitatif yaitu dengan cara mengumpulkan, mengklasifikasikan, menganalisis dan menginterpretasikan data-data yang diperoleh dari perusahaan sehingga dapat memberikan gambaran dengan keadaan yang sebenarnya [2]. 
Seluruh perusahaan di sektor pertambangan yang terdaftar di Bursa Efek Indonesia (BEI) tahun 2017-2019 menjadi populasi penelitian ini. Sumber data yaitu data sekunder. Teknik pengambilan sampel yaitu purposive sampling dengan kriteria:

1. perusahaan di sektor pertambangan yang terdaftar di BEI tahun 2017-2019.

2. Perusahaan menyajikan laporan keuangan secara lengkap

3. Laporan keuangan disajikan dalam mata uang Rupiah. kriteria .

Dari populasi sebanyak 47 perusahaan, hanya 10 perusahaan yang memadai 37 perusahaan yang tidak memenuhi kriteria diantaranya 5 perusahaan tidak terdaftar di BEI pada tahun 2017-2019, 32 perusahaan diantaranya tidak menyajikan laporan keuangan dalam mata uang Rupiah, juga 18 perusahaan tidak menyajikan laporan keuangan lengkap selama periode penelitian.

Tabel 1. Sampel Penelitian

\begin{tabular}{ccl}
\hline NO & $\begin{array}{l}\text { Kode } \\
\text { Saham }\end{array}$ & \multicolumn{1}{c}{ Nama Perusahaan } \\
\hline 1 & ANTM & PT.Aneka Tambang Tbk \\
2. & CITA & PT.Cita Mineral Investindo Tbk \\
3. & CTTH & PT.Citatah Tbk \\
4. & DKFT & PT.Central Omega Resources Tbk \\
5. & MITI & PT.Mitra Investindo Tbk \\
6. & PKPK & PT.Perdana Karya Perkasa Tbk \\
7. & PTBA & PT.Bukit Asam Tbk \\
8. & RUIS & PT.Radiant Utama Interinsco Tbk \\
9. & SMMT & PT.Golden Eagle Energy Tbk \\
10. & TINS & PT.Timah Tbk \\
Sumber: Data sekunder diolah penulis, 2020
\end{tabular}

\section{Definisi Operasional}

Variabel dan definisi operasional penelitian ini dapat dilihat pada Tabel 2. Indikator yang penulis gunakan mengacu pada Darsono dan Ashari (2).

Tabel 2.Variabel dan Definisi Operasional

\begin{tabular}{|c|c|c|c|}
\hline Variabel & Definisi Operasional & Indikator & Skala \\
\hline \multirow[t]{4}{*}{$\begin{array}{l}\text { Rasio } \\
\text { Arus Kas }\end{array}$} & $\begin{array}{l}\text { Rasio Arus Kas terdiri dari } 2 \text { rasio } \\
\text { likuiditas dan rasio fleksibilitas yaitu : } \\
\text { Rasio Likuiditas }\end{array}$ & & \\
\hline & $\begin{array}{l}\text { 1. Rasio Arus Kas Operasi (AKO) } \\
\text { 2. Rasio cakupan kas terhadap bunga } \\
\text { (CKB) }\end{array}$ & $\begin{array}{l}>1=\text { Baik } \\
>1 \text { = Baik }\end{array}$ & Rasio \\
\hline & $\begin{array}{l}\text { 3. Rasio cakupan terhadap hutang } \\
\text { lancar (CKHL) }\end{array}$ & $>0,4=$ Baik & \\
\hline & $\begin{array}{l}\text { 4. Rasio Pengeluaran Modal (PM) } \\
\text { 5. Rasio Total Hutang (TH) }\end{array}$ & $\begin{array}{l}>1=\text { BaiK } \\
>0,2=\text { Baik }\end{array}$ & \\
\hline
\end{tabular}


6. Rasio Cakupan Arus Dana (CAD) $>1=$ Baik

\section{Rasio Fleksibilitas}

1.Rasio Kecukupan Arus Kas (KAK) > $>1=$ Baik

2.Rasio Arus Kas Bersih Bebas (AKBB) $>1=$ Baik

Rasio

Sumber: Data sekunder diolah penulis, 2020

\section{Sumber dan Teknik Pengumpulan Data}

Sumber data untuk penelitian ini data sekunder yaitu berupa laporan keuangan perusahaan sektor pertambangan yang diperoleh melalui situs resmi Bursa Efek Indonesia yaitu www.idx.co.id, dan website resmi perusahaan disektor pertambangan., data kepustakaan, artikel dan jurnal serta penelitian terdahulu yang relevan dengan penelitian ini. Penulis menggunakan data kuantitatif dan teknik dokumentasi yaitu memakai laporan keuangan perusahaan tahun 2017-2019.

\section{Metode dan Teknik Analisis Data}

Pada penelitian ini penulis menggunakan analisis kuantitatif dan kualitatif. Dengan mengunakan formula untuk memperoleh nilai rasio arus kas yang terdiri dari 8 rasio. kemudian dianalisis secara kualitatif dengan menyandingkan hasil perhitungan dengan indikator masing-masing model.

Penulis memakai analisis rasio arus kas sebagai teknik analisis data. Adapun kedelapan rasio yang digunakan yaitu sebagai berikut :

1. Rasio Arus Kas Operasi (AKO)

$\mathrm{A} K O=\frac{\text { Jumlah Arus Kas Operasi }}{\text { Kewajiban Lancar }}$

2.Rasio Cakupan Arus Dana (CAD)

$$
C A D=\frac{\text { EBIT }}{\text { Bunga }+ \text { Pajak }+ \text { Dividen }}
$$

3.Rasio Cakupan Kas terhadap Bunga (CKB)

$$
C K B=\frac{\text { Arus Kas Operasi }+ \text { Pembayaran Bunga }+ \text { Pajak }}{\text { pembayaran Bunga }}
$$

4.Rasio Cakupan Kas terhadap Hutang Lancar (CKHL)

$$
C K H L=\frac{\text { Arus Kas Operasi }+ \text { Dividen }}{\text { Hutang Lancar }}
$$

5) Rasio Pengeluaran Modal

$$
P M=\frac{\text { Arus Kas Operasi }}{\text { Pengeluaran Modal }}
$$

6) Rasio Total Hutang (TH)

$$
T H=\frac{\text { Arus Kas Operasi }}{\text { Total Hutang }}
$$


Rasio Fleksibilitas Arus Kas , terdiri dari 2 rasio :

$$
\begin{aligned}
& \text { 7.Rasio Kecukupan Arus Kas (KAK) } \\
& K A K=\frac{\text { EBIT }- \text { Bunga }- \text { Pajak }- \text { Pengeluaran Modal }}{\text { Rata }- \text { rata Hutang Lancar selama } 5 \text { tahun }} \\
& \text { 8.Rasio Arus Kas Bersih Bebas (AKBB) } \\
& =\frac{\text { Laba Besih+Bunga+ Depresiasi }+ \text { Leasing+Deviden-Peng.Modal }}{\text { Bunga }+ \text { Hutang Jangka Panjang+Hutang Leasing }}
\end{aligned}
$$

\section{Hasil Dan Pembahasan}

Pada penelitian ini, penulis melakukan suatu analisis terhadap kinerja keuangan dengan mamakai rasio arus kas dari sepuluh (10) perusahaan pertambangan yang telah sesuai dengan kriteria selama tiga (3) tahun pengamatan. Rasio yang digunakan untuk menilai kinerja keuangan yaitu Rasio Likuiditas Arus Kas yang terdiri dari Rasio AKO, Rasio CKB, Rasio CKHL, Rasio PM) Rasio TH, Rasio CAD, dan Rasio Fleksibilitas Arus Kas yang terdiri dari Rasio KAK dan Rasio AKBB. Penjelasan mengenai nilai rasio akan dibahas satu-persatu berikut.

\section{Rasio Likuiditas Arus Kas}

\section{Rasio Arus Kas Operasi (AKO)}

Rasio Arus Kas Operasi (AKO) dipakai dalam memprediksi kapabilitas arus kas operasi untuk menyelesaikan kewajiban lancar. Rasio Arus Kas Operasi didapat dari jumlah arus kas operasi dibagi kewajiban jangka pendek. Rasio Arus Kas Operasi suatu perusahaan dikatakan baik jika bernilai tidak kurang dari 1 (satu). Hasil perhitungan rasio Arus Kas Operasi (AKO) pada perusahaan pertambangan periode tahun 20172019, dapat dilihat pada Tabel 3.

Tabel 3. Hasil Perhitungan Rasio Arus Kas Operasi (AKO)

\begin{tabular}{rllccc}
\hline No & Kode & Nama Perusahaan & 2017 & 2018 & 2019 \\
\hline 1 & ANTM & PT.Aneka Tambang Tbk & 0,25 & 0,34 & 0,3 \\
2 & CITA & PT.Cita Mineral Investindo Tbk & $-0,03$ & 0,36 & 0,36 \\
3 & CTTH & PT.Citatah Tbk & 0,36 & 0,11 & 0,03 \\
4 & DKFT & PT.Central Omega Resources Tbk & 0,03 & 0,1 & 0,06 \\
5 & MITI & PT.Mitra Investindo Tbk & 0,03 & 0,01 & $-0,31$ \\
6 & PKPK & PT.Perdana Karya Perkasa Tbk & 1,49 & 11,5 & 0,16 \\
7 & PTBA & PT.Bukit Asam Tbk & 0,55 & 1,59 & 1,00 \\
8 & RUIS & PT.Radiant Utama Interinsco Tbk & 0,07 & 0,05 & 0,09 \\
9 & SMMT & PT.Golden Eagle Energy Tbk & 0,08 & 0,03 & 0,35 \\
10 & TINS & PT.Timah Tbk & 0,04 & 0,19 & 0,17 \\
\hline
\end{tabular}

Sumber : Data Sekunder Diolah Penulis, 2020

Berdasarkan Tabel.3 diketahui bahwa pada tahun 2017, hanya satu dari sepuluh perusahaan yang memiliki nilai rasio diatas 1 sedangkan sembilan sisanya 
memiliki nilai rasio dibawah 1 . Perusahaan yang menunjukkan rasio CAD dibawah 1 artinya perusahaan tersebut dinilai memiliki kemungkinan tidak mampu membayar kewajiban lancar, dengan menggunakan arus kas operasi. Aktivitas operasi merupakan aktivitas utama perusahaan, yang diharapkan mampu menutupi kewajiban lancar perusahaan. Berdasarkan Rasio AKO Tahun 2017 hanya PT.Perdana Karya Perkasa Tbk yang dianggap memiliki kemampuan membayar hutang lancar dengan aktivitas operasinya dan nilai rasio AKO meningkat delapan (8) kali lipat pada tahun 2018. Tahun 2018, nilai rasio AKO PT.Bukit Asam Tbk naik ke titik aman dengan nilai 1,59 dan turun 37\% di tahun 2019. Pada tahun 2019, enam perusahaan mengalami penurunan nilai rasio, termasuk PT.Perdana Karya Perkasa Tbk. Pada Tabel 3, dapat dilihat Rasio AKO PTBA tahun 2019 adalah 1 atau 100\%. Artinya untuk 100 rupiah kewajiban lancar dapat dijamin dengan arus kas operasi senilai 100 rupiah arus kas operasi. Atau dengan kata lain dengan kata lain bahwa PTBA memiliki kemampuan arus kas operasi dalam membayar kewajiban lancarnya sebesar $100 \%$ dari total kewajiban lancar yang dimiliki oleh PTBA.

\section{Rasio Cakupan Arus Dana (CAD)}

Penggunaan Rasio Cakupan Arus Dana (CAD) dipercaya dapat memprediksi kapabilitas perusahaan dalam menghasilkan kas yang nantinya akan digunakan untuk menyelesaikan komitmen-komitmen seperti bunga, pajak dan dividen. Rasio ini dihitung dengan membagi EBIT dengan pembayaran bunga, pajak dan dividen perusahaan pada periode yang sama.

Suatu perusahaan dikatakan memiliki Rasio Cakupan Arus Dana (CAD) yang baik jika nilai rasio tidak kurang dari 1 (satu).

Tabel 4. Hasil Perhitungan Rasio Cakupan Arus Dana (CAD)

\begin{tabular}{rllccc}
\hline No & Kode & Nama Perusahaan & 2017 & 2018 & 2019 \\
\hline 1 & ANTM & PT.Aneka Tambang Tbk & 9,90 & 0,88 & 0,74 \\
2 & CITA & PT.Cita Mineral Investindo Tbk & 0,75 & 5,60 & 3,98 \\
3 & CTTH & PT.Citatah Tbk & 0,40 & 0,40 & 0,36 \\
4 & DKFT & PT.Central Omega Resources Tbk & $-32,94$ & $-1,30$ & $-1,32$ \\
5 & MITI & PT.Mitra Investindo Tbk & $-0,72$ & 0,36 & $-2,79$ \\
6 & PKPK & PT.Perdana Karya Perkasa Tbk & $-1,10$ & $-0,27$ & $-0,29$ \\
7 & PTBA & PT.Bukit Asam Tbk & 6,68 & 1,18 & 1,00 \\
8 & RUIS & PT.Radiant Utama Interinsco Tbk & 0,84 & 0,92 & 0,51 \\
9 & SMMT & PT.Golden Eagle Energy Tbk & 2,09 & 3,52 & 0,30 \\
10 & TINS & PT.Timah Tbk & 2,68 & 1,91 & $-0,28$ \\
\hline
\end{tabular}

Sumber : Data Sekunder Diolah Penulis, 2020

Berdasarkan hasil perhitungan Rasio Cakupan Arus Dana pada Tabel 4 dapat diketahui bahwa pada tahun 2017 hanya empat dari sepuluh perusahaan yang memiliki kategori nilai baik, yaitu PT.Aneka Tambang Tbk, PT.Bukit Asam Tbk, PT.Timah Tbk, dan PT.Golden Eagle Energy Tbk. Selanjutnya tahun 2018 PT.Aneka Tambang Tbk tergabung dalam perusahaan yang memiliki nilai tidak baik.dan digantikan oleh PT.Cita Mineral Investindo Tbk. Tahun 2019 hanya dua perusahaan yang bertahan memiliki nilai minimal 1 yaitu PT.Cita Mineral Investindo Tbk dan 
PT.Bukit Asam Tbk. Dapat kita simpulkan selama tiga periode pengamatan hanya PT Bukit Asam Tbk yang konsisten memiliki kinerja baik berdasarkan Rasio Cakupan Arus Dana. Pada tahun 2019, Nilai Rasio CAD CITA adalah 3,98 atau 398\%. Artinya untuk 100 rupiah bunga, pajak dan dividen dapat dijamin dengan EBIT-Laba Bersih sebelum bunga dan pajak senilai 398 rupiah. Dengan kata lain CITA memiliki kemampuan untuk melunasi komitmen seperti pajak, deviden dan bunga sebesar 398\% menggunakan laba bersih sebelum bunga dan pajak.

\section{Rasio Cakupan Kas Terhadap Bunga}

Rasio ini mengukur kemampuan arus kas operasi perusahaan dalam menutup beban bunga. Formula untuk menghitung nilai rasio ini yaitu Arus Kas Operasi ditambah pembayaran bunga dan pajak, kemudian dibagi dengan pembayaran bunga. Arus kas operasi suatu perusahaan dinilai mampu menutup biaya bunga jika nilai rasio minimal 1 (satu).

Mayoritas perusahaan pertambangan memiliki kemungkinan mampu membayar bunga yang sangat tinggi. Hasil perhitungan Rasio cakupan kas terhadap bunga sampel penelitian dapat dilihat pada Tabel 5 .

Tabel 5. Hasil Perhitungan Rasio Cakupan Kas Terhadap Bunga

\begin{tabular}{cllccc}
\hline No & Kode & Nama Perusahaan & 2017 & 2018 & 2019 \\
\hline 1 & ANTM & PT.Aneka Tambang Tbk & 4,61 & 7,69 & 5 \\
2 & CITA & PT.Cita Mineral Investindo Tbk & 1,36 & 8,92 & 12,68 \\
3 & CTTH & PT.Citatah Tbk & 8,07 & 3,66 & 4,4 \\
4 & DKFT & PT.Central Omega Resources Tbk & 11,38 & 3 & 2,19 \\
5 & MITI & PT.Mitra Investindo Tbk & 12,37 & 8,16 & 8,51 \\
6 & PKPK & PT.Perdana Karya Perkasa Tbk & 2,04 & 6 & 1,85 \\
7 & PTBA & PT.Bukit Asam Tbk & 39,73 & 123,6 & 77,63 \\
8 & RUIS & PT.Radiant Utama Interinsco Tbk & 1,92 & 2,08 & 2,25 \\
9 & SMMT & PT.Golden Eagle Energy Tbk & 1,51 & 3,44 & 3,14 \\
10 & TINS & PT.Timah Tbk & 2,07 & 4,95 & 3,8 \\
\hline
\end{tabular}

Sumber : Data Sekunder Diolah Penulis, 2020

Jika dilihat dari konsistensinya selama tiga tahun, semua perusahaan memiliki nilai diatas standar namun rata-rata mengalami penurunan kemampuan dalam menyelesaikan beban bunga ditahun 2019. Dari kesepuluh perusahaan, hanya PT.Cita Mineral Investindo, Tbk yang konsisten dan mengalami peningkatan kemampuan membayar bunga sebesar 5,5 kali di tahun 2018 dan meningkat lagi 50\% di tahun 2019. Tahun 2019 , rasio Cakupan Kas Terhadap Bunga CITA adalah 12,68 artinya setiap 1 Rupiah beban bunga mampu dijamin sebesar 12,68 Rupiah dari Arus Kas Operasi.

\section{Rasio Cakupan terhadap Hutang Lancar (CKHL)}

Rasio CKHL memprediksi kemampuan suatu entitas dalam melunasi kewajiban jangka pendek dengan berdasar pada arus kas operasi. Rasio CKHL ini didapatkan dengan membandingkan nilai Arus Kas Operasi dan dividen terhadap hutang lancar. Perusahaan dikatakan memiliki kemampuan yang baik dari arus kas operasi dalam 
https://akuntansi.pnp.ac.id/jam

e-ISSN 2657-1080, p-ISSN 1858-3687

menutup hutang jangka pendek jika nilai rasio CKHL perusahaan minimal 0,4. Berikut ini hasil perhitungan CKHL perusahaan pertambangan tahun 2017-2019 yang dapat dilihat pada Tabel 6.

Tabel 6. Hasil Perhitungan Rasio Cakupan terhadap Hutang Lancar

\begin{tabular}{cllccc}
\hline No & Kode & Nama Perusahaan & 2017 & 2018 & 2019 \\
\hline 1 & ANTM & PT.Aneka Tambang Tbk & 0,25 & 0,35 & 0,1 \\
2 & CITA & PT.Cita Mineral Investindo Tbk & $-0,03$ & 0,39 & 0,36 \\
3 & CTTH & PT.Citatah Tbk & 0,36 & 0,11 & 0,11 \\
4 & DKFT & PT.Central Omega Resources Tbk & 0,03 & 0,09 & 0,04 \\
5 & MITI & PT.Mitra Investindo Tbk & 0,03 & 0,01 & $-0,27$ \\
6 & PKPK & PT.Perdana Karya Perkasa Tbk & 1,49 & 11,5 & 164,2 \\
7 & PTBA & PT.Bukit Asam Tbk & 0,69 & 2,97 & 2,27 \\
8 & RUIS & PT.Radiant Utama Interinsco Tbk & 0,08 & 0,06 & 0,04 \\
9 & SMMT & PT.Golden Eagle Energy Tbk & 0,08 & 0,31 & 0,19 \\
10 & TINS & PT.Timah Tbk & 0,07 & 0,21 & 0,29 \\
\hline Sumber $:$ Data Sekunder Diolah Penulis,2020
\end{tabular}

Sumber : Data Sekunder Diolah Penulis, 2020

Dari hasil perhitungan Tabel 6, hanya dua dari sepuluh perusahaan yang konsisten memiliki kemampuan membayar hutang jangka pendek dengan hanya bersumber dari arus kas operasi yaitu PT.Perdana Karya Perkasa Tbk dan PT.Bukit Asam Tbk, sedangkan delapan lainnya tidak. Sedangkan untuk perusahaan yang memiliki nilai terkecil yaitu MITI. Di tahun 2019 bahkan nilai rasio Cakupan hutang lancar PT MITI adalah $(-0,27)$ artinya PT MITI dianggap tidak mampu melunasi hutang lancarnya berdasarkan perhitungan rasio ini. Rasio terbaik diperoleh oleh PKPK yakni 164,2 artinya setiap 1 rupiah hutang lancar mampu dijamin 164,2 rupiah berdasarkan Arus Kas Operasi dan dividen PT.Perdana Karya Perkasa Tbk.

\section{Rasio Pengeluaran Modal (PM)}

Rasio Pengeluaran modal ini menaksir seberapa banyak modal siap digunakan untuk investasi dan pembayaran hutang. Rasio Pengeluaran Modal ini diperoleh dengan membandingkan arus kas operasional terhadap pengeluaran modal perusahaan. Menurut rasio ini suatu perusahaan memiliki kemampuan yang tinggi dalam membiayai pengeluaran modal dari arus kas operasi jika rasio bernilai lebih dari satu(1).

Tabel 7. Hasil Perhitungan Rasio Pengeluaran Modal

\begin{tabular}{rllccc}
\hline No & Kode & Nama Perusahaan & 2017 & 2018 & 2019 \\
\hline 1 & ANTM & PT.Aneka Tambang Tbk & 0,59 & 0,88 & 0,38 \\
2 & CITA & PT.Cita Mineral Investindo Tbk & $-4,94$ & 2,95 & 1,9 \\
3 & CTTH & PT.Citatah Tbk & 1,22 & 1,11 & 1,26 \\
4 & DKFT & PT.Central Omega Resources Tbk & 0,06 & 0,96 & 1,73 \\
5 & MITI & PT.Mitra Investindo Tbk & 5,12 & 6,07 & $-123,07$ \\
6 & PKPK & PT.Perdana Karya Perkasa Tbk & 1,12 & - & - \\
7 & PTBA & PT.Bukit Asam Tbk & 2,23 & 4,79 & 7,12 \\
8 & RUIS & PT.Radiant Utama Interinsco Tbk & 2,56 & 1,42 & 0,21 \\
9 & SMMT & PT.Golden Eagle Energy Tbk & 1,2 & 3,04 & 7,23 \\
10 & TINS & PT.Timah Tbk & 0,19 & 1,22 & 2,9 \\
\hline
\end{tabular}

Sumber : Data Sekunder Diolah Penulis, 2020 
Berdasarkan Tabel 7, diketahui bahwa pada tahun 2017, terdapat lima (5) dari sepuluh (10) perusahaan sampel yang memiliki kemampuan yang tinggi dalam membiayai pengeluaran modal dari arus kas operasi. Lima perusahaan tersebut yaitu PT.Citatah Tbk, PT.Mitra Investindo Tbk, PT.Bukit Asam Tbk, PT.Radiant Utama Interinsco Tbk, PT.Golden Eagle Energy Tbk. Pada tahun 2018, terdapat penambahan jumlah perusahaan yang memiliki nilai baik yaitu PT.Cita Mineral Investindo Tbk dan PT.Timah Tbk sehingga menjadi 7 perusahaan. Tahun 2019, nilai Arus Kas Operasi PT.Mitra Investindo Tbk turun drastis menjadi ( $\mathrm{Rp}$ 13.659.398.439) yang menghantarkan nilai rasio menjadi $(123,07)$. Sehingga dapat disimpulkan dari tiga tahun pengamatan, hanya tiga perusahaan yang konsisten memiliki nilai rasio baik yaitu PT.Citatah Tbk, PT.Bukit Asam Tbk, dan PT.Golden Eagle Energy Tbk. Nilai rasio Pengeluaran Modal terbesar adalah PT.Golden Eagle Energy Tbk yaitu 7,23 artinya setiap 1 rupiah pengeluaran modal mampu dijamin oleh arus kas operasi sebesar 7,23 rupiah atau dengan kata lain $723 \%$.

\section{Rasio Total Hutang (TH)}

Rasio ini untuk mengetahui kemampuan perusahaan dalam membayar semua kewajiban (jangka pendek dan jangka panjang) menggunakan arus kas yang dihasilkan dari aktivitas operasi perusahaan. Sebagai indikator rasio total hutang adalah nilai batas 0,2. Jika nilai Rasio total hutang 0,2 atau lebih artinya perusahaan mempunyai kemampuan yang baik dalam membayar semua kewajibannya dari arus kas yang berasal dari aktivitas normal operasi perusahaan. Untuk perhitungan Rasio total hutang 10 perusahaan sampel dapat dilihat pada Tabel 8.

Tabel 8. Perhitungan Rasio Total Hutang

\begin{tabular}{rllccc}
\hline No & Kode & Nama Perusahaan & 2017 & 2018 & 2019 \\
\hline 1 & ANTM & PT.Aneka Tambang Tbk & 0,12 & 0,14 & 0,1 \\
2 & CITA & PT.Cita Mineral Investindo Tbk & $-0,02$ & 0,28 & 0,22 \\
3 & CTTH & PT.Citatah Tbk & 0,21 & 0,07 & 0,07 \\
4 & DKFT & PT.Central Omega Resources Tbk & 0,02 & 0,07 & 0,02 \\
5 & MITI & PT.Mitra Investindo Tbk & 0,02 & 4,8 & $-0,17$ \\
6 & PKPK & PT.Perdana Karya Perkasa Tbk & 0,06 & 0,05 & 0 \\
7 & PTBA & PT.Bukit Asam Tbk & 0,3 & 1 & 0,86 \\
8 & RUIS & PT.Radiant Utama Interinsco Tbk & 0,05 & 0,03 & 0,03 \\
9 & SMMT & PT.Golden Eagle Energy Tbk & 0,03 & 0,1 & 0,1 \\
10 & TINS & PT.Timah Tbk & 0,03 & 0,2 & 0,2 \\
\hline
\end{tabular}

Sumber : Data Sekunder Diolah Penulis, 2020

Berdasarkan perhitungan rasio total hutang pada Tabel 8, diketahui bahwa tidak semua perusahaan memiliki nilai rasio yang cukup aman untuk membayar semua kewajibannya dengan mengandalkan arus kas operasi saja. Pada tahun 2017 hanya 2 perusahaan pertambangan yang memiliki nilai rasio tipis diatas 0,2 yaitu PT.Citatah Tbk $(0,21)$ dan PT.Bukit Asam Tbk $(0,3)$. Kemudian meningkat ditahun 2018 menjadi 4 perusahaan pertambangan yang memiliki nilai rasio diatas 0,2 yaitu PT.Cita Mineral Investindo Tbk, PT.Mitra Investindo Tbk, dan PT.Timah Tbk. Di tahun 2019 hanya 3 perusahaan. Namun dilihat dari konsistensi nilai rasio hanya PT.Bukit Asam Tbk, 
https://akuntansi.pnp.ac.id/jam

perusahaan pertambangan yang memiliki nilai rasio diatas 0,2 selama 3 tahun pengamatan.

PTBA memiliki nilai rasio terbesar diantara 9 perusahaan tambang lainnya. Di tahun 2018 nilai rasio meningkat menjadi 1. Artinya 100 rupiah hutang jangka pendek maupun jangka panjang mampu dijamin sebesar 100 rupiah menggunakan arus kas operasi perusahaan. Mulai adanya pembatasan skala besar berdampak pada turunnya nilai rasio Total Hutang ini pada PTBA.

\section{Rasio Kecukupan Arus Kas (KAK)}

Rasio kecukupan arus kas merupakan rasio yang dapat digunakan untuk mengukur fleksibilitas melalui arus kas. Rasio ini dihitung dari :

KAK $=\quad$ EBIT-Bunga yg dibayarkan-Pajak-Pengeluaran Modal Rata-Rata Hutang Lancar selama 5 tahun

Suatu entitas dikatakan tidak mampu atau memiliki kemampuan perusahaan yang rendah dalam menyediakan kas untuk memenuhi kewajibannya selama 5(lima) tahun mendatang jika nilai Rasio KAK dibawah 1(satu). Perhitungan rasio kecukupan arus kas perusahaan pertambangan tahun 2017 hingga 2019 dapat dilihat pada Tabel 9.

Tabel 9. Perhitungan Rasio Kecukupan Arus Kas

\begin{tabular}{rllccc}
\hline No & Kode & Nama Perusahaan & 2017 & 2018 & 2019 \\
\hline 1 & ANTM & PT.Aneka Tambang Tbk & 11,41 & $-4,92$ & $-1,43$ \\
2 & CITA & PT.Cita Mineral Investindo Tbk & $-0,12$ & 3,03 & 2,54 \\
3 & CTTH & PT.Citatah Tbk & $-0,3$ & $-0,59$ & $-0,45$ \\
4 & DKFT & PT.Central Omega Resources Tbk & $-5,32$ & $-1,83$ & $-1,58$ \\
5 & MITI & PT.Mitra Investindo Tbk & $-2,89$ & $-2,52$ & $-4,86$ \\
6 & PKPK & PT.Perdana Karya Perkasa Tbk & $-27,4$ & $-4,9$ & $-66,31$ \\
7 & PTBA & PT.Bukit Asam Tbk & 10,26 & 11,16 & 4,96 \\
8 & RUIS & PT.Radiant Utama Interinsco Tbk & $-0,85$ & $-0,96$ & $-1,93$ \\
9 & SMMT & PT.Golden Eagle Energy Tbk & 0,87 & 2,72 & 0,47 \\
10 & TINS & PT.Timah Tbk & $-0,87$ & $-1,17$ & $-1,5$ \\
\hline Sumber $:$ Data Sekunder Diolah Penulis, 2020
\end{tabular}

Sumber : Data Sekunder Diolah Penulis, 2020

Berdasarkan Tabel 9 , dapat dilihat bahwa hanya tiga perusahaan yang memiliki nilai rasio kecukupan arus kas diatas 1 untuk tahun 2017 yaitu PT.Aneka Tambang Tbk, PT.Bukit Asam Tbk dan PT.Golden Eagle Energy Tbk. Di tahun 2018 dan 2019 juga hanya tiga perusahaan yang dinilai memiliki kemampuan dalam menyediakan kas untuk memenuhi kewajibannya selama 5(lima) tahun mendatang. Dari tiga periode pengamatan hanya satu perusahaan yang konsisten memiliki nilai rasio diatas 1 yaitu PT.Bukit Asam Tbk. Nilai rasio kecukupan arus kas tahun 2019 yaitu 4,96 artinya perusahaan memiliki kemampuan 4,96 kali untuk memenuhi kewajibannya selama 5 tahun mendatang dari laba sebelum pajak dan bunga serta pajak dan pengeluaran modal. 
https://akuntansi.pnp.ac.id/jam

8.Rasio Arus Kas Bersih Bebas (AKBB).

Rasio AKBB digunakan untuk memprediksi kapabilitas perusahaan untuk menyelesaikan kewajiban kas dimasa depan. Rasio ini dihitung dari laba bersih, beban bunga, depresiasi dan amortisasi, biaya sewa dan leasing operasi, dividen dan pengeluaran modal, serta hutang jangka panjang dan hutang leasing.

Menurut rasio AKBB, Perusahaan yang memiliki nilai rasio dibawah 1 (satu) menunjukkan ketidakmampuan perusahaan untuk bertahan dan berkembang dimasa depan. Perhitungan Rasio Arus Kas Bersih Bebas Perusahaan Pertambangan tahun 2017 -2019 dapat dilihat pada Tabel 10.

Tabel 10. Perhitungan Rasio Arus Kas Bersih Bebas

\begin{tabular}{rclccc}
\hline No & Kode & Nama Perusahaan & 2017 & 2018 & 2019 \\
\hline 1 & ANTM & PT.Aneka Tambang Tbk & $-0,28$ & $-0,1$ & 0,08 \\
2 & CITA & PT.Cita Mineral Investindo Tbk & 0,18 & 1,16 & 1,08 \\
3 & CTTH & PT.Citatah Tbk & 0,1 & 0,08 & 0,02 \\
4 & DKFT & PT.Central Omega Resources Tbk & $-0,68$ & $-0,1$ & 0,06 \\
5 & MITI & PT.Mitra Investindo Tbk & 5,1 & 6,78 & 6,98 \\
6 & PKPK & PT.Perdana Karya Perkasa Tbk & $-0,04$ & - & - \\
7 & PTBA & PT.Bukit Asam Tbk & 1,13 & 2,24 & 1,83 \\
8 & RUIS & PT.Radiant Utama Interinsco Tbk & 1,26 & 1,2 & $-0,9$ \\
9 & SMMT & PT.Golden Eagle Energy Tbk & 0,25 & 0,56 & 0,26 \\
10 & TINS & PT.Timah Tbk & 0 & $-0,1$ & $-0,1$ \\
\hline Sumber $:$ Data Sekunder Diolah Penulis, 2020 & & &
\end{tabular}

Berdasarkan Perhitungan pada Tabel 10, diketahui di tahun 2017 hanya tiga (3) perusahaan yang dinilai dengan rasio ini mampu bertahan dan berkembang yaitu PT.Mitra Investindo Tbk, PT.Bukit Asam Tbk, dan PT.Radiant Utama Interinsco Tbk. Sedangkan ditahun 2018 terdapat empat (4) perusahaan yaitu penambahan PT.Cita Mineral Investindo Tbk. Ditahun 2019 , PT.Radiant Utama Interinsco Tbk tidak lagi termasuk dalam perusahaan yang memilki nilai rasio diatas 1 . Jika dilihat dari tiga tahun penelitian, hanya terdapat dua (2) perusahaan yang konsisten memiliki nilai rasio AKBB baik yaitu PT.Bukit Asam Tbk dan PT.Mitra Investindo Tbk. Nilai terbesar diraih oleh PT.Mitra Investindo Tbk yakni 6,98, artinya setiap setiap 1 rupiah hutang jangka panjang PT MITI ini mampu dijaminkan 6,98 kali atau 6,98 Rupiah yang berasal dari laba bersih, depresiasi dan amortisasi, biaya sewa dan leasing operasi, dividen dan pengeluaran modal.

Berdasarkan hasil perhitungan 8(delapan) rasio arus kas yang telah disajikan pada tabel-tabel sebelumnya, dapat disimpulkan bahwa hanya beberapa perusahaan pertambangan yang konsisten memiliki kinerja baik. Nama perusahaan yang memiliki kinerja baik selama tiga tahun periode pengamatan dapat dilihat pada Tabel 11.

Tabel 11. Perusahaan yang Memiliki Kinerja Baik selama 2017-2019 Berdasarkan 8 Rasio Arus Kas

\begin{tabular}{llcll}
\hline No & Rasio Arus Kas & Nilai & KODE & Nama Perusahaan \\
\hline 1 & Rasio Arus Kas Operasi & $>1$ & PKPK & PT.Perdana Karya Perkasa Tbk \\
& & & (2017\&2018) \\
& & PTBA & PT.Bukit Asam Tbk (2018\&2019) \\
\hline
\end{tabular}




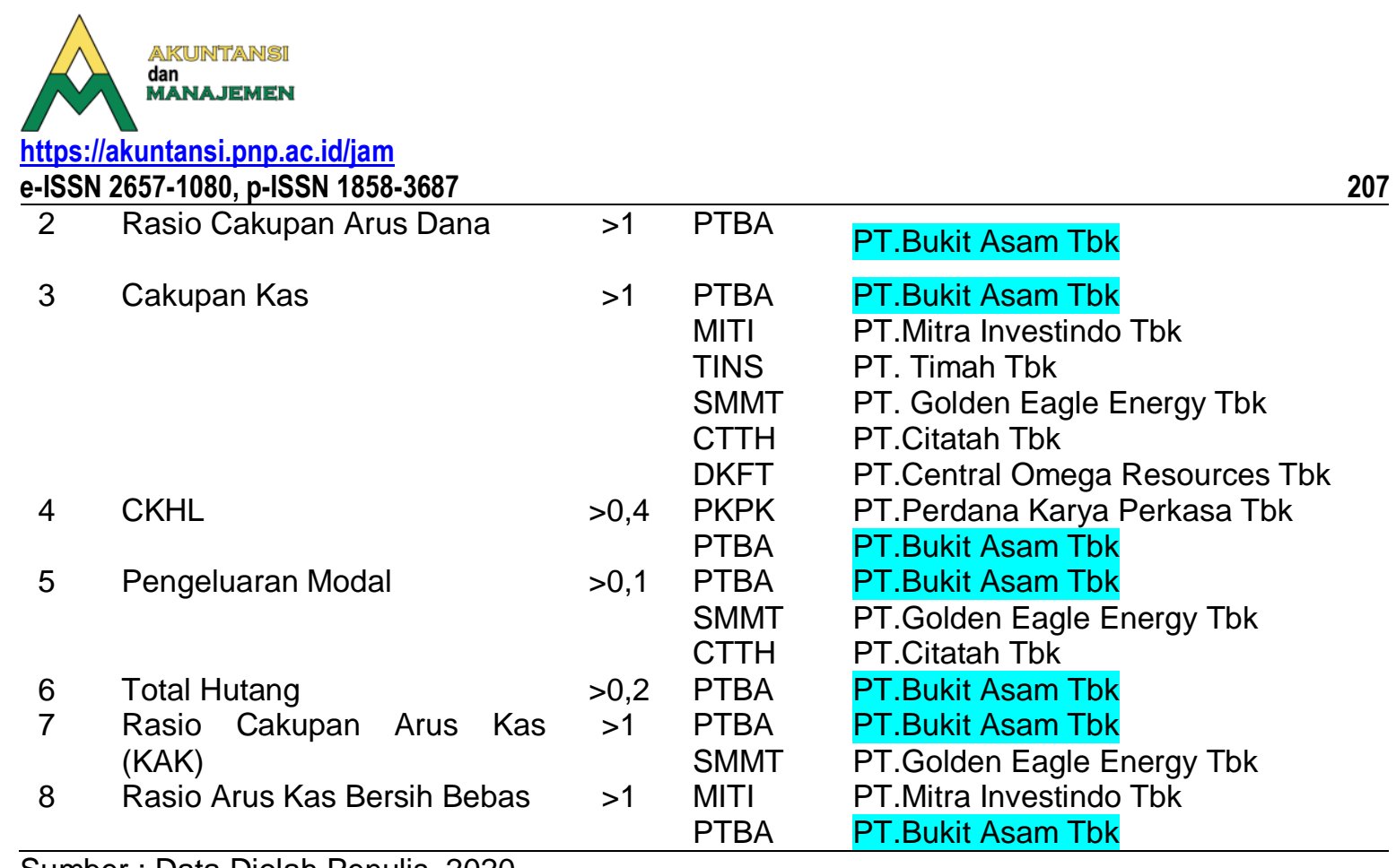

Sumber : Data Diolah Penulis, 2020

Berdasarkan Tabel 11 yang merangkum hasil perhitungan kedelapan rasio arus kas, terlihat bahwa hanya Rasio Cakupan Kas yang paling banyak mampu dicapai oleh perusahaan pertambangan. Terdapat 6 (enam) perusahaan yang memiliki nilai Rasio Cakupan Kas kategori baik (>1) yaitu PT.Bukit Asam Tbk, PT.Mitra Investindo Tbk, PT. Timah Tbk, PT. Golden Eagle Energy Tbk, PT.Citatah Tbk, PT.Central Omega Resources Tbk.

Sedangkan nilai Rasio Cakupan Arus Dana dan Rasio Total Hutang yang berada kriteria baik selama 3 (tiga) tahun berturut-turut hanya dicapai oleh PT Bukit Asam Tbk. Begitupula dengan kelima rasio lainnya, hanya dua perusahaan yang konsisten memiliki nilai diatas standar selama 3 tahun periode pengamatan, dan hanya PT Bukit Asam Tbk yang konsisten memiliki rasio diatas standar dari 7 rasio arus kas.

\section{Analisis Rasio Arus Kas Sebelum dan Setelah Pandemi}

Pada Tabel 12 ditampilkan perbandingan nilai rasio arus kas perusahaan pertambangan sebelum dan setelah pandemi semalama tiga (3) Triwulan yakni triwulan 1 tahun 2019 dibandingkan dengan Triwulan 1 tahun 2020. Kemudian Rasio arus kas pada Triwulan kedua tahun 2019 dibandingkan dengan Triwulan kedua tahun 2020. Terakhir Rasio arus kas pada Triwulan ketiga tahun 2019 dibandingkan dengan Triwulan ketiga tahun 2020. Dibandingkan setiap triwulan yang sama atas dasar pertimbangan kemiripan aktivitas bisnis pada setiap triwulannya.

Tabel 12

Perbandingan Rasio Arus Kas Perusahaan Pertambangan

Sebelum dan Selama Pandemi Covid-19

\begin{tabular}{llcccccc}
\hline 1 & \multicolumn{2}{l}{ PT.Aneka Tambang Tbk } & & & & & \\
\\
KODE & RASIO & \multicolumn{2}{c}{ Triwulan 1 } & \multicolumn{2}{c}{ Triwulan 2 } & \multicolumn{2}{c}{ Triwulan 3 } \\
\hline \multirow{4}{*}{ ANTM } & & 2019 & 2020 & 2019 & 2020 & 2019 & 2020 \\
& AKO & 0,159 & 0,003 & 0,137 & 0,028 & 0,044 & 0,254 \\
& CAD & 1,083 & $-1,306$ & 1,201 & 0,400 & 10,925 & 2,290 \\
& CKB & 9,701 & 2,980 & 5,167 & 2,204 & 2,344 & 5,378 \\
\hline
\end{tabular}




$\begin{array}{lcccccc}\text { CKHL } & 0,159 & 0,003 & 0,137 & 0,028 & 0,044 & 0,254 \\ \text { PM } & & & & & & \\ \text { TH } & 0,068 & 0,001 & 0,064 & 0,011 & 0,020 & 0,093 \\ \text { KAK } & -2,132 & -9,860 & -1,967 & -9,000 & 11,722 & -7,196 \\ \text { AKBB } & -0,089 & -0,571 & -0,049 & -0,474 & -0,008 & -0,352\end{array}$

2 PT.Cita Mineral Investindo Tbk

\begin{tabular}{llcccccc} 
KODE & RASIO & \multicolumn{2}{c}{ Triwulan 1 } & \multicolumn{2}{c}{ Triwulan 2 } & \multicolumn{2}{c}{ Triwulan 3 } \\
& & 2019 & 2020 & 2019 & 2020 & 2019 & 2020 \\
CITA & AKO & 0,096 & 0,012 & 0,202 & 0,659 & 0,084 & 0,771 \\
& CAD & 13,269 & 0,345 & 4,935 & 1,307 & 3,978 & 1,434 \\
& CKB & 8,493 & 1,434 & 11,626 & 48,591 & 6,402 & 62,062 \\
& CKHL & 0,096 & 0,012 & 0,202 & 0,659 & 0,084 & 0,771 \\
& TH & 0,068 & 0,109 & 0,146 & 0,575 & 0,062 & 0,690 \\
& KAK & $-0,005$ & $-0,011$ & $-0,004$ & $-0,007$ & $-0,003$ & $-0,006$ \\
& AKBB & $-1,312$ & $-0,204$ & $-0,789$ & $-6,137$ & $-0,402$ & $-4,275$
\end{tabular}

3 PT.Citatah Tbk

\begin{tabular}{llllllll} 
KODE & RASIO & \multicolumn{2}{c}{ Triwulan 1 } & \multicolumn{2}{c}{ Triwulan 2 } & \multicolumn{2}{c}{ Triwulan 3 } \\
KODE & RASIO & 2019 & 2020 & 2019 & 2020 & 2019 & 2020 \\
CTTH & AKO & 0,027 & $-0,039$ & 0,030 & 0,000 & 0,108 & 0,006 \\
& CAD & 1,219 & $-3,487$ & 0,153 & $-2,248$ & $-0,374$ & $-1,635$ \\
& CKB & 4,153 & $-1,110$ & 3,212 & 1,532 & 4,332 & 1,877 \\
& CKHL & 0,027 & $-0,039$ & 0,030 & 0,000 & 0,108 & 0,006 \\
& PM & & & & & & \\
& TH & 0,016 & $-0,024$ & 0,018 & 0,000 & 0,065 & 0,004 \\
& KAK & $-0,029$ & $-0,003$ & $-0,029$ & $-0,003$ & $-0,030$ & $-0,004$ \\
& AKBB & $-5,573$ & $-0,497$ & $-5,595$ & $-0,513$ & $-5,451$ & $-0,511$
\end{tabular}

4 PT.Central Omega Resources Tbk

\begin{tabular}{|c|c|c|c|c|c|c|c|}
\hline \multirow[t]{2}{*}{ DKFT } & \multirow[t]{2}{*}{ RASIO } & \multicolumn{2}{|c|}{ Triwulan 1} & \multicolumn{2}{|c|}{ Triwulan 2} & \multicolumn{2}{|c|}{ Triwulan 3} \\
\hline & & 2019 & 2020 & 2019 & 2020 & 2019 & 2020 \\
\hline & AKO & 0,042 & 0,008 & 0,082 & $-0,146$ & 0,038 & 0,200 \\
\hline & CAD & 0,655 & $-0,004$ & 0,005 & $-0,085$ & $-0,011$ & $-0,002$ \\
\hline & CKB & 1,078 & 5,805 & 5,069 & 4,576 & 4,922 & 1,968 \\
\hline & $\mathrm{CKHL}$ & 2,141 & 0,008 & 1,874 & $-0,146$ & 1,778 & 0,200 \\
\hline & \multicolumn{7}{|l|}{ PM } \\
\hline & $\mathrm{TH}$ & 0,021 & 0,005 & 0,052 & $-0,077$ & 0,025 & 0,103 \\
\hline & KAK & $-0,047$ & $-0,842$ & $-0,022$ & $-0,025$ & $-0,022$ & $-0,851$ \\
\hline & AKBB & 1,813 & 0,896 & 1,269 & $-0,008$ & 1,223 & 0,968 \\
\hline
\end{tabular}

5 PT.Mitra Investindo Tbk

\begin{tabular}{cccccccc} 
KODE & RASIO & \multicolumn{2}{c}{ Triwulan 1 } & \multicolumn{2}{c}{ Triwulan 2 } & Triwulan 3 & \\
& & 2019 & 2020 & 2019 & 2020 & 2019 & 2020 \\
MITI & AKO & 0,099 & $-0,050$ & 0,155 & $-0,108$ & 0,270 & $-0,123$ \\
& CAD & 0,000 & 0,000 & 0,000 & 0,000 & 0,000 & 0,000
\end{tabular}




$\begin{array}{lcccccc}\text { CKB } & 3,978 & 4,416 & 3,904 & 3,984 & 3,905 & 4,112 \\ \text { CKHL } & 0,099 & -0,050 & 0,155 & -0,108 & 0,270 & -0,123 \\ \text { PM } & & & & & & \\ \text { TH } & 0,063 & -0,031 & 0,098 & -0,069 & 0,170 & -0,079 \\ \text { KAK } & -5,242 & -5,679 & -5,147 & -5,125 & -5,147 & -5,291 \\ \text { AKBB } & 0,898 & 0,995 & 0,897 & 0,995 & 0,897 & 0,995\end{array}$

6 PT.Perdana Karya Perkasa Tbk

\begin{tabular}{clcccccc} 
KODE & RASIO & \multicolumn{2}{c}{ Triwulan 1 } & \multicolumn{2}{c}{ Triwulan 2 } & Triwulan 3 & \\
& & 2019 & 2020 & 2019 & 2020 & 2019 & 2020 \\
PKPK & AKO & 0,900 & 0,528 & 0,900 & $-31,43$ & 0,432 & $-1,414$ \\
& CAD & 0,000 & 0,000 & 0,000 & 0,000 & $-0,001$ & 0,000 \\
& CKB & 0,000 & 1,000 & 1,000 & 1,000 & 1,000 & 0,999 \\
CKHL & 0,900 & 0,528 & 0,900 & $-31,43$ & 0,432 & $-1,414$ \\
PM & & & & & & \\
TH & 0,004 & 0,019 & 0,004 & $-0,04$ & 0,001 & $-0,22$ \\
KAK & $-66,67$ & $-60,671$ & $-66,673$ & $-60,64$ & $-60,65$ & $-60,65$ \\
AKBB & 0,894 & 0,994 & 0,894 & 0,993 & 0,992 & 0,996
\end{tabular}

7 PT.Bukit Asam Tbk

\begin{tabular}{llcrrrrr} 
KODE & RASIO & \multicolumn{2}{c}{ Triwulan 1 } & \multicolumn{2}{c}{ Triwulan 2 } & \multicolumn{2}{c}{ Triwulan 3 } \\
& & 2019 & 2020 & 2019 & 2020 & 2019 & 2020 \\
PTBA & & 0,265 & 0,265 & 0,499 & 0,294 & 0,800 & 0,816 \\
& CAD & 3,240 & 9,363 & 4,001 & 3,575 & 6,686 & 5,489 \\
\hline & CKB & 64,209 & 46,681 & 67,642 & 62,546 & 36,401 & 65,020 \\
CKHL & 0,265 & 0,265 & 0,499 & 0,294 & 0,800 & 0,817 \\
PM & & & & & & \\
TH & 0,154 & 0,358 & 0,301 & 0,204 & 0,497 & 0,451 \\
KAK & 0,000 & 0,002 & 0,002 & 0,003 & 0,005 & 0,004 \\
& AKBB & 0,057 & 0,277 & 0,370 & 0,397 & 0,721 & 0,497
\end{tabular}

8 PT.Radiant Utama Interinsco Tbk

\begin{tabular}{|c|c|c|c|c|c|c|c|}
\hline \multirow[t]{2}{*}{ KODE } & \multirow[t]{2}{*}{ RASIO } & \multicolumn{2}{|c|}{ Triwulan 1} & \multicolumn{2}{|c|}{ Triwulan 2} & \multicolumn{2}{|l|}{ Triwulan 3} \\
\hline & & 2019 & 2020 & 2019 & 2020 & 2019 & 2020 \\
\hline \multirow[t]{8}{*}{ RUIS } & AKO & 0,0098 & $-0,085$ & 2,09E-05 & $-0,017$ & 0,141 & $-0,036$ \\
\hline & CAD & 0,96147 & 0,124 & 0,802109 & 0,690 & 0,684 & 0,861 \\
\hline & CKB & 1,536 & $-2,041$ & 1,651767 & 1,000 & 2,993 & 0,479 \\
\hline & CKHL & 0,009 & $-0,084$ & $2,09 \mathrm{E}-05$ & $-0,017$ & 0,141 & $-0,036$ \\
\hline & PM & & & & & & \\
\hline & $\mathrm{TH}$ & 0,00767 & $-0,056$ & $1,45 \mathrm{E}-05$ & $-0,012$ & 0,098 & $-0,027$ \\
\hline & KAK & $-0,0148$ & $-0,001$ & $-8,9 \mathrm{E}-05$ & 0,000 & 0,000 & 0,000 \\
\hline & AKBB & $-7,0141$ & 0,010 & 0,00013 & 0,124 & 0,218 & 0,196 \\
\hline
\end{tabular}


9 PT.Golden Eagle Energy Tbk

\begin{tabular}{llrrrrrr} 
KODE & RASIO & \multicolumn{2}{c}{ Triwulan 1} & \multicolumn{2}{c}{ Triwulan 2 } & Triwulan 3 & \\
& & 2019 & 2020 & 2019 & 2020 & 2019 & 2020 \\
SMMT & AKO & 0,109 & 0,024534 & 0,121 & 0,015 & 0,186 & 0,002 \\
& CAD & 0,003 & $-4,09662$ & 0,002 & $-0,046$ & 0,904 & $-0,091$ \\
& CKB & 1,039 & 1,790829 & 1,020 & 47,694 & 2,002 & 24,131 \\
CKHL & 0,109 & 0,024534 & 0,121 & 0,015 & 0,186 & 0,002 \\
PM & & & & & & \\
TH & 0,057 & 0,012175 & 0,064 & 0,008 & 0,103 & 0,001 \\
KAK & $-0,254$ & $-0,00156$ & $-0,502$ & $-0,011$ & $-0,138$ & $-0,010$ \\
AKBB & 0,974 & $-0,15392$ & 0,988 & $-0,112$ & 0,993 & $-0,115$
\end{tabular}

10 PT. Timah Tbk

\begin{tabular}{llcccccc} 
KODE & RASIO & \multicolumn{2}{c}{ Triwulan 1 } & \multicolumn{2}{c}{ Triwulan 2 } & Triwulan 3 & \\
& & 2019 & 2020 & 2019 & 2020 & 2019 & 2020 \\
TINS & AKO & 0,145 & 0,123 & 0,272 & 0,320 & 0,269 & 0,596 \\
& CAD & 0,251 & $-0,002$ & 0,057 & $-0,001$ & $-0,386$ & 0,007 \\
& CKB & 1,896 & 1,006 & 1,968 & 1,008 & 6,712 & 1,009 \\
CKHL & 0,145 & 0,123 & 0,272 & 0,320 & 0,269 & 0,596 \\
PM & & & & & & \\
TH & 0,112 & 0,095 & 0,225 & 0,234 & 0,201 & 0,410 \\
KAK & $-0,002$ & $-0,313$ & $-0,046$ & $-5,660$ & $-0,012$ & $-7,598$ \\
AKBB & 0,445 & 0,984 & 0,610 & 0,990 & 0,071 & 0,993
\end{tabular}

Sumber : Data Sekunder Diolah Penulis, 2020

Berdasarkan Tabel 12 dapat dilihat bahwa meskipun beberapa rasio di perusahaan ada yang meningkat seperti PT. Bukit Asam Tbk dan Golden PT.Golden Eagle Energy Tbk, namun secara mayoritas terjadi penurunan nilai rasio arus kas setelah terjadi pandemi yakni tahun 2020, baik triwulan 1, Triwulan 2 maupun Triwulan 3.dan nilai masih sebagian besar dibawah standar baik.

Pada PT.Aneka Tambang Tbk, sebelum pandemi yaitu Triwulan I,II,dan III Rasio Cakupan Arus Dana dan Rasio Cakupan Kas terhadap Bunga terkategori baik, Namun setelah pandemi, terjadi penurunan nilai pada kedua rasio ini, bahkan Rasio Cakupan Arus Dana masuk pada kategori tidak baik pada Triwulan I dan II tahun 2020. Pada PT.Cita Mineral Investindo Tbk, sebelum pandemi yaitu Rasio Cakupan Arus Dana dan Rasio Cakupan Kas terhadap Bunga terkategori baik. Setelah pandemi Rasio Cakupan Arus Dana mengalami penurunan nilai, bahkan kategori tidak baik menurut rasio ini pada triwulan pertama di tahun 2020. Namun berbeda dengan rasio Rasio Cakupan Kas terhadap Bunga,yang mengalami peningkatan nilai rasio pada triwulan II dan III di tahun 2020.

PT. Citatah Tbk, sebelum pandemi Rasio Cakupan Kas terhadap Bunga terkategori baik selama 3 triwulan di tahun 2019 dan Cakupan Arus Dana hanya pada 
triwulan pertama. Setelah pandemi, kedua nilai rasio ini mengalami penurunan yang sangat signifikan. Nilai EBIT atau Laba Sebelum Bunga dan Pajak yang mengalami defisit, membuat nilai rasio Rasio Cakupan Kas bernilai negatif pada triwulan I,II dan III.

PT.Central Omega Resources Tbk, dari ketujuh rasio yang digunakan hanya Rasio Cakupan Kas terhadap Bunga yang masih terkategori baik pada ketiga triwulan 2019 dan 2020, meski meningkat lebih dari 4x lipat pada triwulan pertama, namun anjlok pada triwulan kedua dan ketiga tahun 2020 dibandingkan dengan tahun 2019. Sedangkan rasio CKHL dan rasio AKBB yang semula terkategor baik di triwulan I,II,III sebelum pandemi, menurun terjam di triwulan I,II,dan III tahun 2020nya.

PT.Mitra Investindo Tbk, hanya satu rasio yang terkategori baik berdasarkan rasio arus kas yaitu Cakupan Kas terhadap Bunga, dan berbeda dengan perusahaan pada umumnya, justru perusahaan ini mengalami peningkatan nilai rasio. Artinya kemampuan membayar bunga berasal dari kas semakin membaik. PT.Perdana Karya Perkasa Tbk, tidak ada rasio yang konsisten terkategori baik namun rasio CKHL dan rasio CKB sempat terkategori baik di tahun 2019 kemudian menjadi tidak baik selama pandemi melanda.

PT.Bukit Asam Tbk, sebagai perusahaan yang memiliki kinerja paling baik dari 10 perusahaan pertambangan yang diteliti. Rasio CAD ,CKB dan TH terkategori baik sebelum pandemi dan sebagian memiliki nilai rasio yang meningkat juga sebagian menurun pada tahun 2020. PT.Golden Eagle Energy Tbk, hanya satu rasio yang terkategori baik yaitu rasio CKB namun justru memiliki nilai yang lebih tinggi selama pandemi Covid-19. Sedangakn PT. Timah Tbk, hanya rasio CKB yang terkategori baik berdasarkan indikator rasio arus kas, dan juga mengalami penurunan yang drastis dibandingkan dengan tahun 2020, tahun dimana pandemi Covid-19 sedang melanda.

Aktifitas sektor pertambangan cukup banyak terdampak akibat pandemi Covid19 terutama karena kebijakan yang dipilih selama pandemi. Terdapat beberapa negara yang menggunakan kebijakan lockdown yaitu dengan menutup semua akses kegiatan guna menghindari orang untuk berkerumun dan kontak langsung. Namun tidak semua negara menggunakan kebijakan lockdown untuk sektor tambang, namun umumnya tetap menerapkannya dengan protokol yang ketat. Setelah adanya beberapa tenaga kerja terkena pandemi baru beberapa perusahaan memberhentikan sementara tambang. Kebijakan lockdown ini mengakibatkan beberapa aktifitas perusahaan tambang berhenti berproduksi dan ini tentunya mempengaruhi produksi serta pendapatan perusahaan. Akibatnya lebih lanjut, target operasi menjadi mundur hingga tahun 2024.

Secara umum adanya kebijakan lockdown ini telah mempengaruhi produksi dan konsumsi sehingga mempengaruhi perdagangan terutama ekspor impor bahan tambang. Lockdown yang dilakukan China, India, Italy atas intruksi pemerintahan negara tersebut menyebaban berhentinya kegiatan pertambangan di negara tersebut untuk melakukan produksi. Produksi yang terhenti akan berakibat pada supply beberapa komoditas mengalami penurunan. Kebijakan ini mengakibatkan terjadinya perbedaan dan sekaligus mengganggu harga komoditas tambang. Indonesia tidak menggunakan kebijakan lockdown ke bidang pertambangan dikarenakan kontribusi pendapatan negara terbesar diklaim masih berasal dari sektor pertambangan. Selama tahun 2019, jumlah setoran ke negara dari sektor ini mencapai sekitar Rp. 172,9 triliun [19] . inipun belum mencapai target nasional Rp. 214,3 triliun atau sekitar 81\% dari 
target nasional [11]. Tentunya kebijakan lockdown menjadi pilihan yang sangat hatihati karena cukup berpengaruh terhadap ekonomi nasional

Selain itu, dampak pandemi Covid-19 ini, menyebabkan terjadinya penurunan permintaan dan prospek kedepan yang tidak pasti dan pasar yang lesu. Permintaan terbesar yang biasanya berasal dari China,Korea dan India mengalami penurunan permintaan terutama untuk support kepada industri mereka. Karena perlambatan ekonomi di negara importir batubara seperti China dan Korea akibat penyebaran virus corona.

Target investasi sektor pertambangan minerba hingga Oktober 2020 baru mencapai 37,3\% dari target tahun ini. Hal tersebut disampaikan Irwandy Arif dalam sebuah diskusi bertema 'Prospek Sektor Tambang di tengah Ketidakpastian Ekonomi Global' secara virtual, Selasa (10 November 2020). Realisasi investasi pada tahun lalu itu menurutnya berasal dari izin usaha jasa pertambangan 39\%, prasarana dan mesin $30 \%$, aktiva tidak berwujud $13 \%$, bangunan, kapal, kendaraan dan alat-alat berat $23 \%$.

\section{Kesimpulan Dan Saran Kesimpulan}

Berdasarkan rasio arus kas disimpulkan mayoritas perusahaan pertambangan belum memiliki kinerja yang baik. Dari kedelapan rasio hanya Rasio Cakupan Kas yang paling banyak mampu dicapai oleh perusahaan pertambangan. Terdapat 6 (enam) perusahaan yang memiliki nilai Rasio Cakupan Kas kategori baik ( $>1)$ yaitu PT.Bukit Asam Tbk, PT.Mitra Investindo Tbk, PT. Timah Tbk, PT. Golden Eagle Energy Tbk, PT.Citatah Tbk, PT.Central Omega Resources Tbk. Keenam perusahaan ini dianggap memiliki kemampuan arus kas operasi perusahaan dalam menutup beban bunga perusahaan .

Sedangkan nilai Rasio Cakupan Arus Dana dan Rasio Total Hutang yang berada kriteria baik selama 3 (tiga) tahun berturut-turut hanya dicapai oleh PT Bukit Asam Tbk. Begitupula dengan kelima rasio lainnya, hanya dua perusahaan yang konsisten memiliki nilai diatas standar selama tiga tahun periode pengamatan, dan hanya PT Bukit Asam Tbk yang konsisten memiliki rasio diatas standar dari 7 (tujuh) rasio arus kas.

Jika dibandingkan nilai rasio arus kas perusahaan pertambangan semakin menurun dengan adanya pandemi Covid-19. Berbagai dampak yang kian berimbas pada insustri pertambangan seperti pemberlakuan lockdown bagi negara ekspor tujuan, yang berimbas pada terjadinya penurunan permintaan dan pasar yang lesu.

\section{Saran}

Penelitian ini mengalami keterbatasan, salah satunya perbandingan yang dilakukan per triwulan sehingga ada satu rasio (Pengeluaran Modal) yang tidak bisa disajikan dikarenakan tidak terdapat data yang dibutuhkan pada laporan keuangan per triwulan. Berdasarkan hasil penelitian dan keterbatasan yang ada, diharapkan penulis selanjutnya dapat meneliti kinerja keuangan pada industri yang lebih luas, dengan metode berbeda, dengan waktu pengamatan lebih panjang. 


\section{Ucapan Terima Kasih}

Kami mengucapkan terimakasih kepada Yayasan Pendidikan Nasional Tridinanti (YPNT) Universitas Tridinanti Palembang yang telah mendanai penelitian ini.

\section{Referensi}

[1] Arief Sugiono dan Edy Untung. 2016. Panduan Dasar Analisa Laporan Keuangan. Edisi Revisi. PT. Grasindo, Jakarta.

[2] Arikunto, Suharsimi. 2010. Prosedur Penelitian Suatu pendekatan Praktek. Jakarta: Rineka Cipta

[3] Darsono dan Ashari. (2005). Pedoman Praktis Memahami Laporan Keuangan. Andi, Yogyakarta.

[4] Dwi. D. Prastowo. 2015. Analisis Laporan Keuangan. UPP STIM YKPN, Yogyakarta.

[5] Fahmi,Irham. 2014. Manajemen Keuangan Perusahaan dan Pasar Modal. Edisi Pertama. Mitra Wacana Media, Jakarta.

[6] Harahap, Sofyan Syafri. 2016. Analisis Kritis atas Laporan Keuangan. Cetakan Ketigabelas. Rajawali Pers: Jakarta.

[7] Hery. 2017. Analisis Laporan Keuangan. Cetakan Kedua. PT . Grasindo, Jakarta.

[8] Hery. 2016. Analisis Laporan Keuangan. Jakarta: Grasindo

[9] Ikatan Akuntansi Indonesia.(2009). Pernyataaan Standar Akuntansi Keuangan. PSAK No.1 (Revisi 2009): Penyajian Laporan Keuangan. IAI, Jakarta.

[10] Ikatan Akuntansi Indonesia. (2009). Pernyataaan Standar Akuntansi Keuangan. PSAK No.2 (Revisi 2009): Laporan Arus Kas. IAI, Jakarta.

[11] Jatam. 2020. Beban Ganda Warga Sekitar Tambang di Masa,[terhubung berkala] https: //www.mongabay.co.id/2020/08/30/ surveijatam-beban-ganda-warga-sekitartambangdi-masa-pandemi.

[12] Jona W, Megi Sila, dkk.Analisis Rasio Arus Kas Dalam Menilai Kinerja Keuangan pada PT. PLN (Persero) Wilayah Sulutenggo. Jurnal Riset Akuntansi Going Concern 13. 2018. Universitas Sam Ratulangi Manado. Hal. 462.

[13] Kusumawardani, Dwi Sesanti,dkk. Analisis Rasio Keuangan Untuk Menilai Kinerja Keuangan Badan Usaha Milik Negara Yang Terdaftar di BEI Periode 2010-2012.. Jurnal Administrasi Bisnis. 2014. Universitas Brawijaya, Vol.9 No. 02, Hal. 8. Malang.

[14] Meldawati dan Ananda, Febryandhie. 2013. Analisis Rasio Arus Kas Untuk Mengukur Kinerja Keuangan pada PT Kalbe Farma Tbk. STIE KBP. Padang.

[15] Mulyadi. 2007. Akuntansi Manajemen: Konsep, Manfaat dan Rekayasa. Edisi Revisi, Bagian Penerbit Universitas Gajah Mada, Yogyakarta.

[16] Mulyani, Sri. Analisis Rasio Arus Kas Sebagai Alat Pengukur Kinerja Keuangan Perusahaan. Jurnal Dinamika Ekonomi \& Bisnis, Vol. 10 No. 1, Maret, 2013, Hal. 24, STIE Pariwisata,Semarang.

[17] Munawir S. 2010. Analisa Laporan Keuangan. UPP-AMP YKPN, Yogyakarta.

[18] Mursyidi. 2015. Akuntansi Dasar. Cetakan Kedua. Ghalia Indonesia, Bogor.

[19] Putera, I. R. 2020. Capai target, Sumbangan Sektor ESDM ke PNBP Hanya Rp. 172,9 Triliun diunduh pada https://www. merdeka.com/uang/tak-capai-target-sumba ngansektor-esdm-ke-pnbp-hanya-rp1729- triliun.html

[20] Rudianto. 2013.Akuntansi Manajemen: Informasi untuk Pengambilan Keputusan Strategis. Erlangga, Jakarta. 
[21]Rusmanto, \& Mentayani, I. Model Pengukuran Kinerja pada Perusahaan Jasa Konstruksi di Kota Banjarmasin. Jurnal Aplikasi Manajemen. 2011, Vol. 10. No 3.

[22] Sanusi, Anwar. 2011. Metodologi Penelitian Bisnis.Cetakan Keenam. Salemba Empat, Jakarta.

[23] Subramanyam. 2017. Analisis Laporan Keuangan Financial Statement Analysis. Salemba Empat, Jakarta.

[24] Sugiyono. 2016. Metode Penelitian Kuantitatif, Kualitatif, dan R \& D. Alfabeta, Bandung.

[25] Sujarweni, V Wiratna. 2016. Pengantar Akuntansi. Pustaka Baru Press, Yogyakarta.

[26] Syahputra, Fegi. 2014. Analisis Kinerja Keuangan Dengan Menggunakan Laporan Arus Kas Perusahaan Manufaktur yang Terdaftar di BEI. Skripsi: Universitas Negeri Padang. 